\title{
Solubilisasi Fosfat Anorganik oleh Burkholderia spp. pada Rizosfer Kelapa Sawit (Elaeis guineensis Jacq.) di Tanah Mineral Masam
}

\author{
Solubilization of Inorganic Phospate by Burkholderia spp. Associated with Oil Palm \\ Rhizosphere in Mineral Acid Soil \\ Gregorius Baskara Aji Nugraha ${ }^{1 *}$, Ruli Wandri ${ }^{1}$, Dwi Asmono ${ }^{1}$ \\ ${ }^{1}$ Departemen Riset dan Pengembangan, PT. Sampoerna Agro, Tbk., Palembang, 30127 \\ ${ }^{*}$ Penulis untuk korespondensi: baskara.anugraha@gmail.com
}

\begin{abstract}
Phosphate Solubilizing Bacteria (PSB) play important role by enhancing phosphate availability bounded with $\mathrm{Al} 3+$ or $\mathrm{Fe} 3+$ in acidic soils to oil palm plants through release the inorganic phosphate by enzyme or organic acids solubilization. The aims of this study were to isolate of PSB from oil palm rhizosphere and to conduct a comparative analysis of the solubility inorganic phosphates source by selected PSB. The ability of 15 selected PSB to grow and solubilize aluminum phosphate (AlPO4) and iron phosphate (FePO4) was examined and identified. The highest phospate solubilising efficiency showed K3.1 isolate with phosphate solubilization index 3.2 on NBRIP media. Quantitative analysis revealed that isolate $\mathrm{K} 3.1$ solubilized $53.52 \mathrm{mg} / \mathrm{mL}$ phosphate in 5 days after being inoculated in AlPO4 containing liquid medium, isolate A4 solubilized $63.45 \mathrm{mg} / \mathrm{mL}$ phosphate in 5 days after being inoculated in FePO4 containing liquid medium accompanied by a decrease in $\mathrm{pH}$ of the growth medium. Based on the 16s rRNA gene sequence analysis, isolate K3.1 and A.4 were closely related to Burkholderia arboris and Burkholderia gladioli. This potential isolates can be used in order to make oil palm crops more sustainable especially on marginal soil with low $\mathrm{pH}$ and less dependent on inorganic $\mathrm{P}$ fertilizers.
\end{abstract}

Keywords: $\mathrm{AlPO}_{4}$; bacteria; $\mathrm{FePO}_{4}$; NBRIP; 16S rRNA

\begin{abstract}
ABSTRAK
Bakteri Pelarut Fosfat (BPF) berperan penting dengan meningkatkan ketersediaan fosfat yang terikat kompleks dengan $\mathrm{Al}^{3+}$ atau $\mathrm{Fe}^{3+}$ di tanah masam bagi tanaman kelapa sawit melalui mekanisme pelarutan dengan menggunakan enzim maupun asam organik. Tujuan dari penelitian ini adalah mengisolasi BPF dari rizosfer kelapa sawit dan melakukan analisis komparatif sumber kelarutan fosfat anorganik oleh BPF yang dipilih. Kemampuan 15 isolat BPF terpilih dalam melarutkan aluminium fosfat $\left(\mathrm{AlPO}_{4}\right)$ dan besi fosfat $\left(\mathrm{FePO}_{4}\right)$ sudah diteliti dan diidentifikasi. Efisiensi pelarut fosfat tertinggi ditunjukkan isolat K3.1 dengan indeks pelarutan fosfat sebesar 3.2 pada media NBRIP. Pada pengujian kuantitatif, isolat $\mathrm{K} 3.1$ melarutkan $53,52 \mathrm{mg} / \mathrm{mL}$ fosfat dalam 5 hari setelah diinokulasi dalam media cair yang mengandung $\mathrm{AlPO}_{4}$, isolat A4 melarutkan $63,45 \mathrm{mg} / \mathrm{mL}$ fosfat dalam 5 hari setelah diinokulasi dalam media cair yang mengandung $\mathrm{FePO}_{4}$. Berdasarkan analisis urutan gen $16 \mathrm{~S}$ rRNA, isolat K3.1 dan A.4 terkait erat dengan Burkholderia arboris dan Burkholderia gladioli. Isolat potensial ini dapat digunakan untuk membuat pupuk hayati bagi tanaman kelapa sawit terutama pada tanah marginal dengan $\mathrm{pH}$ masam dan mengurangi ketergantungan terhadap pupuk $\mathrm{P}$ anorganik.
\end{abstract}

Kata kunci: $\mathrm{AlPO}_{4}$; bakteri; $\mathrm{FePO}_{4}$; NBRIP; 16S rRNA 


\section{PENDAHULUAN}

Kelapa sawit (Elaeis guineensis Jacq.) merupakan salah satu komoditas unggulan Indonesia karena menghasilkan devisa terbesar dari sektor perkebunan. Kebutuhan minyak nabati dari kelapa sawit untuk industri pangan dan bahan bakar (biodiesel) mengalami peningkatan seiring dengan meningkatnya jumlah penduduk di dunia (Euler et al., 2017; Hoffmann et al., 2017). Perkebunan kelapa sawit di Indonesia merupakan yang terluas di dunia, namun produktivitasnya cukup rendah. Salah satu penyebabnya adalah rendahnya efisiensi pemupukan pada perkebunan kelapa sawit terutama unsur fosfor (Acevedo et al., 2014; Istina et al., 2015).

Fosfor $(\mathrm{P})$ adalah unsur hara makro esensial yang berperan penting bagi pertumbuhan terutama tanaman kelapa sawit. Tanaman yang mengalami defisiensi unsur ini berpotensi terhambat pertumbuhan tanamannya sehingga dapat menyebabkan penurunan produksi (Sarker, Talukder, dan Islam, 2014). Kandungan P pada tanah - tanah suboptimal berada dalam jumlah yang sedikit dan sulit larut di dalam air sehingga diperlukan pemupukan $\mathrm{P}$. Pemupukan $\mathrm{P}$ pada lahan pertanian yang dilakukan secara intensif menyebabkan tanah menjadi jenuh $P$. Efisiensi pemupukan $\mathrm{P}$ hanya berkisar antara $10 \%$ $30 \%$ pada tanah - tanah masam dengan kelarutan $\mathrm{Al}$ dan $\mathrm{Fe}$ yang tinggi (Panda, Rahman dan Panda, 2016; Zheng et al., 2019). Beberapa mikroorganisme seperti bakteri dan jamur memiliki kemampuan untuk melarutkan $\mathrm{P}$ di dalam tanah agar tersedia bagi tanaman. Peran bakteri dalam melarutkan $\mathrm{P}$ lebih banyak digunakan karena bakteri juga mampu menghasilkan senyawa lain seperti asam amino, vitamin dan hormon pemacu tumbuh seperti giberelin dan IAA yang berguna bagi pertumbuhan tanaman (Shahid dan Khan, 2018; Teng et al., 2018; Zheng et al., 2019)

Mekanisme kerja bakteri pelarut fosfat (BPF) dalam melarutkan $\mathrm{P}$ yang berasal dari tanah maupun $\mathrm{P}$ dari aktivitas pemupukan pada suatu lahan pertanian didasarkan kemampuan bakteri dalam mensekresikan asam-asam organik seperti asam sitrat, asam format, asam oksalat, asam laktat, asam asetat, dan, asam malat. Peningkatan asam organik biasanya diikuti dengan pembentukan kelat dari $\mathrm{Al}, \mathrm{Fe}$ dan $\mathrm{Ca}$ oleh asam organik tersebut sehingga $\mathrm{P}$ dapat larut sehingga $\mathrm{P}$ tersedia bagi tanaman meningkat (Behera et al., 2014; Chakdar et al., 2018; Shahid dan Khan, 2018). Tujuan penelitian ini adalah untuk mengisolasi BPF dari rizosfer tanaman kelapa sawit yang unggul berdasarkan kemampuannya melarutkan fosfat yang tidak tersedia untuk tanaman, dan mengidentifikasinya menggunakan teknik molekuler berbasis gen $16 \mathrm{~S}$ rRNA

\section{BAHAN DAN METODE}

\section{Pengambilan Sampel Tanah dan Isolasi Bakteri}

Tanah rizosfer di sekitar tanaman kelapa sawit dikumpulkan dan dibawa ke laboratorium. Sampel tanah $10 \mathrm{~g}$ dipindahkan ke dalam labu erlenmeyer 250 $\mathrm{ml}$ dan dipindahkan ke $90 \mathrm{ml}$ larutan 0,85\% $\mathrm{NaCl}$ steril. Campuran kemudian dikocok selama 30 menit pada $150 \mathrm{rpm}$. Setelah pengocokan, 10 kali pengenceran suspensi dibuat dengan pemipetan $1 \mathrm{ml}$ suspensi ke dalam 9 ml larutan $\mathrm{NaCl} 0,85 \%$ steril. Suspensi 0,1 ml sampel dari masing-masing pengenceran ini dituangkan ke cawan petri dengan media agar National Botanical Research Institute Fosfor (NBRIP) yang mengandung $10 \mathrm{~g}$ glukosa, $3 \mathrm{~g} \mathrm{AlPO}_{4}$ atau $5 \mathrm{~g} \mathrm{FePO}_{4}, 5 \mathrm{~g} \mathrm{MgCl}_{2} .6 \mathrm{H}_{2} \mathrm{O}, 0,25 \mathrm{~g}$ $\mathrm{MgSO}_{4} \cdot 7 \mathrm{H}_{2} \mathrm{O}, 0,2 \mathrm{~g} \mathrm{KCl}, 0,1 \mathrm{~g}\left(\mathrm{NH}_{4}\right) 2 \mathrm{SO}_{4}$ dan $10 \mathrm{~g}$ agar Gellan dalam air suling $1 \mathrm{~L}$ (Nautiyal, 1999). Kadar pH media disesuaikan menjadi 5 menggunakan $\mathrm{HCl}$. Cawan petri diinkubasi selama 7 hari dalam inkubator pada $30^{\circ} \mathrm{C}$. Koloni dengan zona halo dianggap bakteri pelarut fosfat. Bakteri ini selanjutnya dimurnikan dan disimpan dalam agar NBRIP pada suhu $30^{\circ} \mathrm{C}$. Isolat yang digunakan untuk tahap selanjutnya berjumlah 15 isolat. 


\section{Pengujian kualitatif dan kuantitatif pelarutan fosfat}

Kultur bakteri berumur 48 jam yang ditumbuhkan sebelumnya diambil sebanyak $3 \mu 1$ diinokulasikan pada media NBRIP padat dan diinkubasi selama 10 hari pada suhu ruang. Zona bening yang terbentuk diukur dan dihitung indeks pelarutan fosfatnya. Pengujian kuantitatif $\mathrm{P}$ yang dilarutkan oleh isolat bakteri terpilih (Peix et al., 2001). Sebanyak 1 ose kultur bakteri diinokulasikan ke dalam $50 \mathrm{ml}$ medium NBRIP cair, kemudian diinkubasi dalam inkubator goyang selama 48 jam. Setelah inkubasi, sebanyak $1 \mathrm{ml}$ kultur diinokulasikan ke dalam $100 \mathrm{ml}$ medium NBRIP cair dengan berbagai bentuk fosfat, dan diinkubasi dalam inkubator goyang selama 7 hari pada suhu $30^{\circ}$ C. Setiap 24 jam, sebanyak $1 \mathrm{ml}$ kultur bakteri disentrifugasi pada kecepatan $10.600 \mathrm{~g}$ selama 10 menit untuk memisahkan sel bakteri dari supernatan. Supernatan hasil sentrifugasi diambil sebanyak $1 \mathrm{ml}$ dan direaksikan dengan pereaksi pembentuk warna $(2.5 \mathrm{ml}$ natrium molibdat $2.5 \%$ dan 1 $\mathrm{ml}$ hidrazin sulfat $0.3 \%$ ), kemudian dipanaskan selama 10 menit dan didinginkan. Setelah terbentuk warna biru, aktivitas pelarutan $\mathrm{P}$ diukur dengan spektrofotometer pada panjang gelombang $830 \mathrm{~nm}$. Kurva standar dibuat dengan menggunakan konsentrasi $\mathrm{KH}_{2} \mathrm{PO}_{4}$ untuk standar 0, 20, 40, 60, 80, dan 100 ppm. Setiap perlakuan diulang tiga kali dan data dinyatakan sebagai nilai rata-rata \pm kesalahan standar (SE).

Ekstraksi DNA, Amplifikasi PCR, dan Sekuensing Gen 16S rRNA

DNA genom diisolasi

menggunakan kit DNA genomik QIAamp® mengikuti instruksi dari pabriknya dan gen 16SrRNA diamplifikasi menggunakan primer universal, $27 \mathrm{f} \quad$ (5' AGAGTTTGATCCTGGCTCAG 3') dan 1492

$r$

TACGGCTACCTTGTTACGACTT

yang merupakan pelengkap dari wilayah bakteri yang dilindungi untuk bakteri yang dilindungi. Gen 16Sr RNA. Amplifikasi dilakukan dalam volume reaksi $25 \mu \mathrm{L}$ yang mengandung instruksi dari pabrik berikut. Volume reaksi disesuaikan hingga $25 \mu \mathrm{L}$ dengan air suling ganda. Kondisi siklus termal PCR terdiri dari langkah denaturasi awal pada $94^{\circ} \mathrm{C}$ selama 3 menit, diikuti oleh 30 siklus denaturasi ( 1 menit pada $94^{\circ}$ $\mathrm{C})$, anil selama 1 menit pada $57^{\circ} \mathrm{C}$ dan perpanjangan selama 2 menit pada $72^{\circ} \mathrm{C}$, diikuti oleh ekstensi akhir pada $72^{\circ} \mathrm{C}$ selama 8 menit. Air suling ganda digunakan sebagai kontrol negatif untuk memeriksa false positive sebagai hasil kontaminasi reagen. Produk yang diamplifikasi PCR dipisahkan pada gel agarosa 1,0\% dalam buffer $1 \mathrm{X}$ TBE pada $70 \mathrm{~V} \mathrm{~cm}-1$ selama 20 menit. Gen 16S rRNA parsial dari isolat terpilih di masing-masing kelompok diurutkan oleh FIRSTBASE, Malaysia. Akhirnya, urutan 16S rRNA isolat dibandingkan dengan mikroorganisme lain dengan cara

BLAST (http://www.ncbi.nlm.nih.gov/BLAST/Blas t.cgi).

\section{HASIL}

\section{Pengujian Kualitatif dan Kuantitatif Pelarutan Fosfat}

Strain bakteri yang diisolasi sebanyak 15 isolat mampu melarutkan kalsium fosfat yang ada dalam medium NBRIP dan membentuk zona beningg dengan intensitas yang bervariasi (Gambar 1). Efisiensi Pelarut Fosfat (PSE) berdasarkan diameter koloni dan diameter zona halo untuk isolat bakteri ditunjukkan pada Gambar 2. Efisiensi Pelarut Fosfat tertinggi ditunjukkan isolat $\mathrm{K} 3.1$ (PSE = 3.2) diikuti oleh isolat $\mathrm{A} 1$ ( $\mathrm{PSE}=2.9$ ).

Hasil penelitian ini (Tabel 1) menunjukkan bahwa isolat A.4 memiliki kemampuan tinggi dalam melarutkan besi fosfat $63,5 \mathrm{mg} \mathrm{L}-1$ dan isolat K3.1 yang mampu melarutkan aluminium fosfat tertinggi dengan $53,5 \mathrm{mg} \mathrm{L}-1$ larut fosfat. Sedangkan isolat K3.3 melarutkan fosfat yang berikatan dengan $\mathrm{Ca}$ dengan kelarutan 58,6 mg L-1. 
Ekstraksi DNA, Amplifikasi PCR, dan Sekuensing Gen 16SrRNA

sebagai Burkholderia gladioli, isolat K3.1

Berdasarkan hasil sekuensing,

ketiga isolat dimasukkan dalam genus diidentifikasi sebagai Burkholderia arboris,

Burkholderia spp. Isolat A.4 diidentifikasi dan isolat $\mathrm{K} 3.3$ diidentifikasi sebagai Burkholderia seminalis (Gambar 3).

Tabel 1. Pelarut besi fosfat, aluminium fosfat, dan kalsium fosfat oleh isolat terpilih

\begin{tabular}{|c|c|c|c|c|c|c|c|c|c|c|c|c|}
\hline \multirow{3}{*}{$\begin{array}{l}\text { Isolat } \\
\text { A.1 }\end{array}$} & \multirow{2}{*}{\multicolumn{4}{|c|}{$\begin{array}{l}\text { Strengit-Besi Fosfat } \\
\text { Consentrasi Fosfat Terlarut } \\
\text { (mg L-1) }\end{array}$}} & \multirow{2}{*}{\multicolumn{4}{|c|}{$\begin{array}{c}\text { Variscit-Alumunium Fosfat } \\
\begin{array}{r}\text { Konsentrasi Fosfat Terlarut } \\
(\mathrm{mg} \mathrm{L}-1)\end{array} \\
\end{array}$}} & \multirow{2}{*}{\multicolumn{4}{|c|}{$\begin{array}{c}\text { Apatit-Kalsium Fosfat } \\
\begin{array}{c}\text { Konsentrasi Fosfat Terlarut } \\
\text { (mg L-1) }\end{array}\end{array}$}} \\
\hline & & & & & & & & & & & & \\
\hline & 5.5 & \pm & 0.25 & $\mathrm{a}$ & 1.7 & \pm & 0.44 & $\mathrm{a}$ & 6.3 & \pm & 6.31 & $\mathrm{a}$ \\
\hline A. 10 & 7.3 & \pm & 0.19 & $\mathrm{~b}$ & 45.0 & \pm & 1.98 & $\mathrm{i}$ & 51.7 & \pm & 51.73 & $\mathrm{~h}$ \\
\hline A. 4 & 63.5 & \pm & 2.28 & $\mathrm{~h}$ & 4.6 & \pm & 0.18 & $\mathrm{~b}$ & 57.7 & \pm & 57.70 & $\mathrm{kl}$ \\
\hline B3.10 & 49.1 & \pm & 1.71 & $\mathrm{e}$ & 7.6 & \pm & 0.14 & $\mathrm{~d}$ & 56.4 & \pm & 56.43 & $\mathrm{jk}$ \\
\hline B3.4 & 4.1 & \pm & 0.03 & $\mathrm{a}$ & 22.7 & \pm & 1.25 & $\mathrm{e}$ & 26.7 & \pm & 26.72 & $\mathrm{~d}$ \\
\hline $\mathrm{C} 1.1$ & 4.3 & \pm & 0.05 & $\mathrm{a}$ & 43.1 & \pm & 0.61 & $\mathrm{~h}$ & 47.6 & \pm & 47.60 & g \\
\hline F2.11 & 22.1 & \pm & 0.56 & $\mathrm{c}$ & 0.7 & \pm & 0.36 & $\mathrm{a}$ & 22.1 & \pm & 22.05 & c \\
\hline $\mathrm{F} 2.7$ & 4.3 & \pm & 0.27 & $\mathrm{a}$ & 25.3 & \pm & 0.86 & $\mathrm{f}$ & 29.6 & \pm & 29.58 & $\mathrm{e}$ \\
\hline K1.3 & 4.2 & \pm & 0.29 & $\mathrm{a}$ & 48.7 & \pm & 1.29 & $\mathrm{j}$ & 54.6 & \pm & 54.58 & $\mathrm{i}$ \\
\hline $\mathrm{K} 2.2$ & 58.8 & \pm & 1.13 & $\mathrm{~g}$ & 4.9 & \pm & 0.01 & $\mathrm{~b}$ & 55.3 & \pm & 55.33 & ij \\
\hline $\mathrm{K} 2.4$ & 4.2 & \pm & 0.16 & $\mathrm{a}$ & 44.2 & \pm & 2.11 & hi & 47.7 & \pm & 47.72 & $\mathrm{~g}$ \\
\hline K3.1 & 4.2 & \pm & 0.13 & $\mathrm{a}$ & 53.5 & \pm & 1.21 & $\mathrm{k}$ & 57.1 & \pm & 57.06 & $\mathrm{k}$ \\
\hline K3.3 & 53.6 & \pm & 1.99 & $\mathrm{f}$ & 6.3 & \pm & 0.13 & $\mathrm{bc}$ & 58.6 & \pm & 58.58 & 1 \\
\hline NL & 4.6 & \pm & 0.13 & $\mathrm{a}$ & 36.1 & \pm & 1.52 & $\mathrm{~g}$ & 39.3 & \pm & 39.34 & $\mathrm{f}$ \\
\hline $\mathrm{TB}$ & 30.2 & \pm & 0.89 & $\mathrm{~d}$ & 15.7 & \pm & 0.14 & $\mathrm{~d}$ & 13.1 & \pm & 13.12 & $\mathrm{~b}$ \\
\hline
\end{tabular}

Keterangan :

Angka yang di ikuti oleh huruf yang sama pada kolom yang sama tidak berbeda nyata pada uji DMRT 5\%

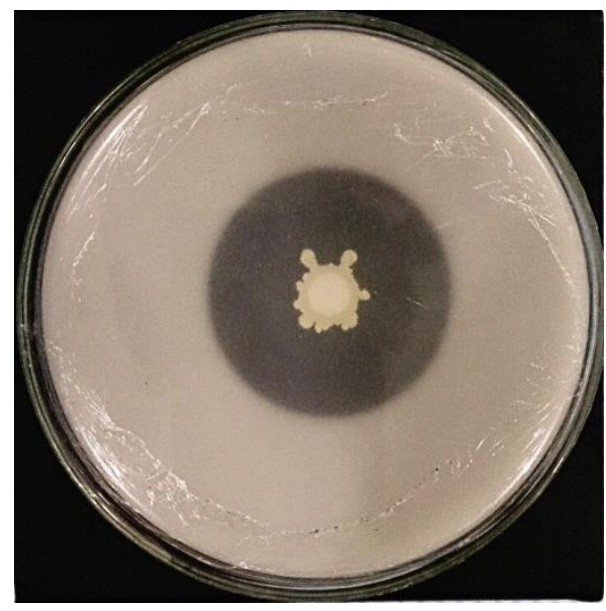

Gambar 1. Uji kualitatif bakteri pelarut fosfat isolat K3.1 pada media NBRIP suhu inkubasi $30^{\circ} \mathrm{C}$ selama 10 hari. 


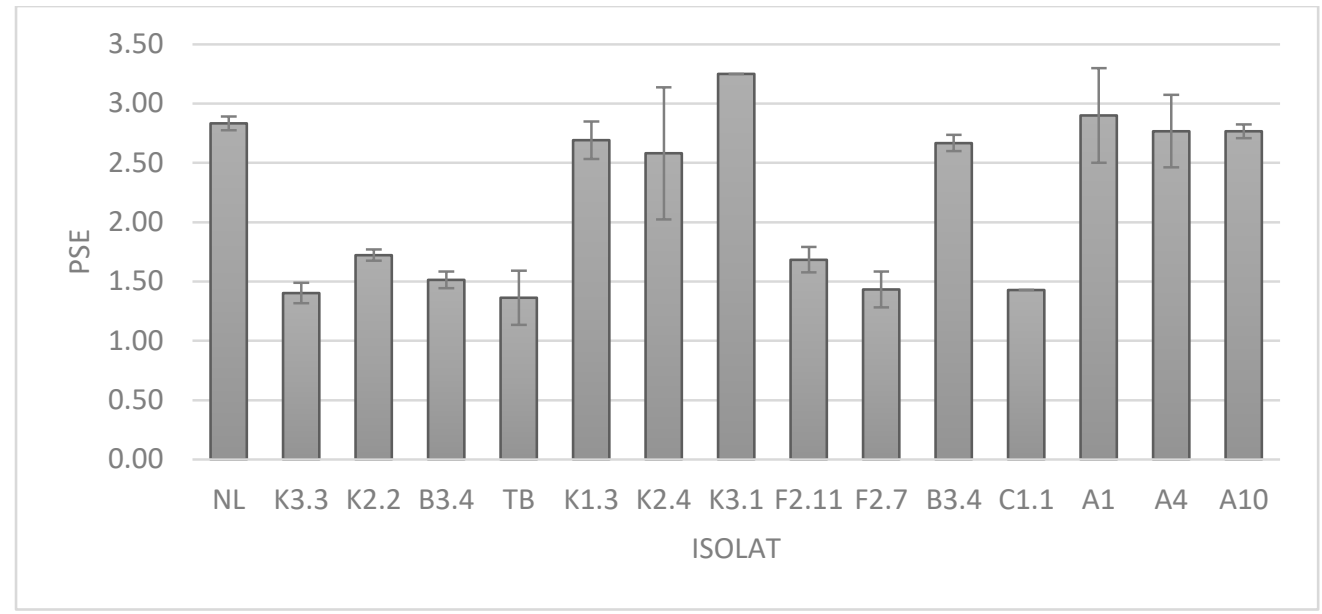

Gambar 2. Efisiensi Pelarut Fosfat (PSE) pada beberapa isolat setelah 10 hari masa inkubasi.

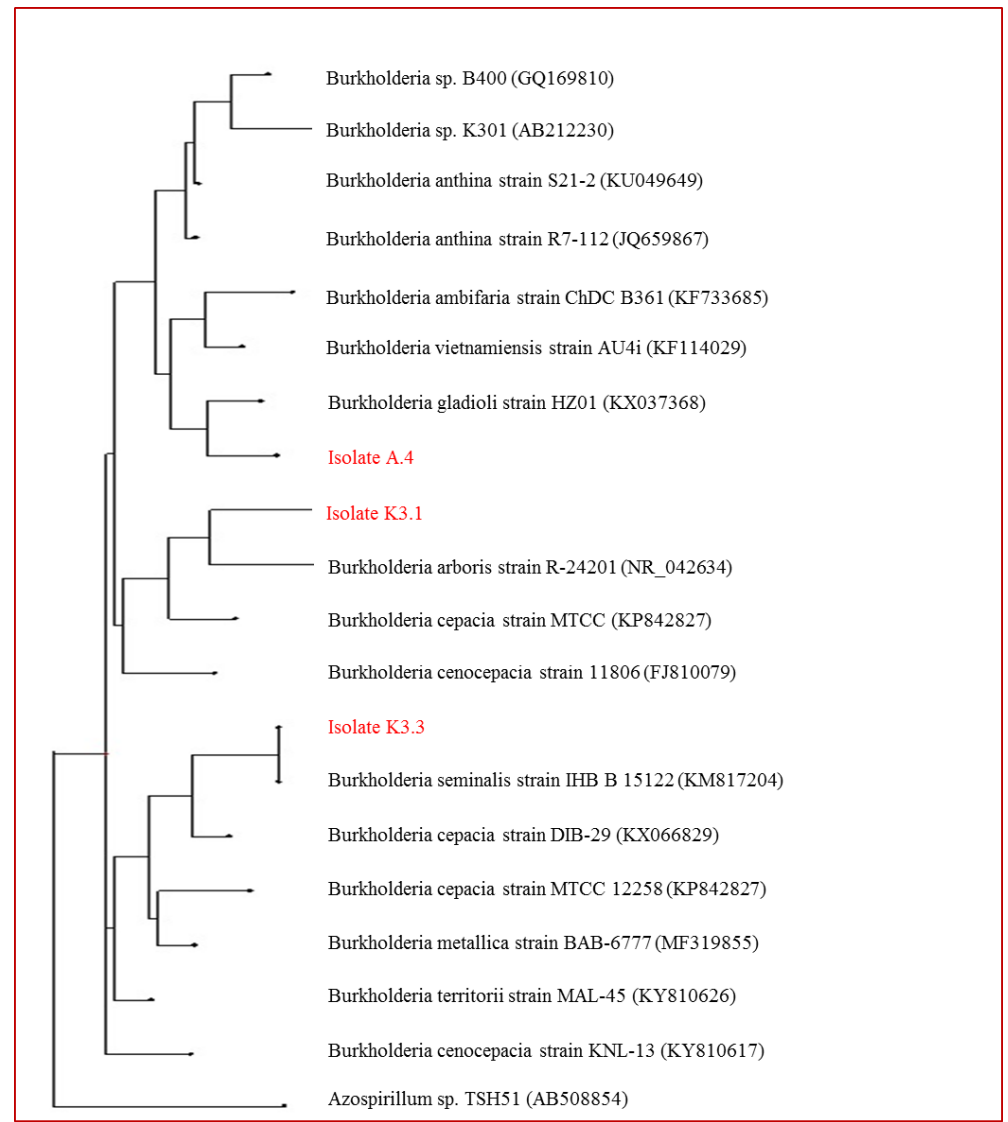

Gambar 3. Pohon filogenetik yang menunjukkan hubungan antara bakteri pelarut fosfat (BPF) dari rizosfer kelapa sawit berdasarkan urutan gen 16S r. 


\section{PEMBAHASAN}

Mikroba pelarut fosfat adalah mikroba yang memiliki kemampuan untuk melarutkan fosfat tak larut menjadi fosfat larut sehingga menjadi bentuk yang tersedia dan dapat diserap oleh tanaman. Mekanisme dari mikroba pelarut fosfat secara umum adalah dengan mensekresikan asam-asam organik jenis tertentu sehingga fosfat yang terikat dengan unsur logam seperti $\mathrm{Ca}, \mathrm{Al}$, maupun $\mathrm{Fe}$ dapat terlepas. Mikroba yang dapat melarutkan fosfat berasal dari kelompok bakteri, fungi, maupun aktinomisetes (Tam, 2017).

Seluruh isolat hasil isolasi dilakukan pengujian kualitatif dalam pelarutan fosfat dengan substrat $\mathrm{Ca} 3 \mathrm{PO} 4$ (Qian et al., 2010). Isolat diuji pada media NBRIP modifikasi kemudian ditumbuhkan pada suhu 270C selama 10 hari dengan pengukuran indeks zona pelarutan dilakukan setiap hari. Hasil ditampilkan pada grafik di bawah ini:

Pada pengujian secara kualitatif didapatkan bahwa isolat yang digunakan dalam penelitian ini mampu menunjukkan zona bening dengan zona pelarutan yang cukup tinggi. Selanjutnya, dilakukan pengujian secara kuantitatif pelarutan fosfat dengan menggunakan spektrofotometer. Pada pengujian ini dihitung kadar fosfat pada media sebelum dan sesudah diinokulasikan dengan isolat BPF. Kadar fosfat yang mengalami peningkatan selama 10 hari inkubasi menunjukkan aktivitas pelarutan fosfat yang tinggi ( $\mathrm{Li}$ et al., 2017).

Pada tanah masam, kelarutan $\mathrm{Al}$ dan $\mathrm{Fe}$ sangat tinggi sehingga ion fosfat (H2PO4-, HPO42, PO43-) akan segera terikat untuk membentuk senyawa $\mathrm{P}$ yang kurang tersedia untuk tanaman. Penggunaan pelarut fosfat mikroba masih menghadapi beberapa kendala seperti faktor tanah, karena masing-masing jenis tanah memiliki bentuk fosfat yang berbeda seperti di tanah didominasi asam fosfat yang didominasi oleh Al-P, Fe-P atau tertambat-P.
Hasil penelitian ini menunjukkan bahwa isolat A.4 memiliki kemampuan tinggi dalam melarutkan besi fosfat $63,5 \mathrm{mg}$ L-1 dan K3.1 isolat yang mampu melarutkan fosfat aluminium tertinggi dengan 53,5 mg L-1 fosfat terlarut.

Pohon filogenetik menunjukkan hubungan antara bakteri pelarut fosfat (PSB) dari rhizhosfer kelapa sawit dalam penelitian ini dan kerabat filogenik terdekat mereka berdasarkan sekuensing gen 16S rRNA. Burkholderia adalah kelompok bakteri yang mampu melarutkan $\mathrm{P}$ dengan memproduksi asam organik (Rodríguez and Fraga, 1999; Saikia et al., 2018) dan biasanya dilaporkan sebagai pertumbuhan PGPR yang mempromosikan rhizobakteria) yang mampu menghasilkan zat yang tumbuh seperti IAA (Grichko and Glick, 2001). Burkholderia dikenal sebagai bakteri fiksasi $\mathrm{N}$ dan memiliki kemampuan (Stephen and Jisha, 2011; Wahdi, Mubarik and Widyastuti, 2016). Burkholderia adalah bakteri efisien yang digunakan sebagai pupuk hayati di lahan pertanian (Nautiyal, 1999). Dalam penelitian ini, sampel tanah rhizosfer dari tanaman kelapa sawit disaring untuk isolasi PSB. Di antara 15 isolat pelarut fosfat, dua PSB efisien dipilih untuk studi solubilisasi anorganik. Menurut analisis urutan 16S rRNA, strain diidentifikasi sebagai Burkholderia spp. Laporan sebelumnya juga menggambarkan beberapa Burkholderia sebagai pelarut fosfat yang efisien (Fuentes-Ramı et al., 2001; Peix et al., 2001; Sin and Viruel, 2011).

\section{KESIMPULAN}

Isolat A.4 memiliki kemampuan tinggi dalam melarutkan besi fosfat $63,5 \mathrm{mg}$ $\mathrm{L}-1$ dan isolat K3.1 yang mampu melarutkan aluminium fosfat tertinggi dengan 53,5 mg L-1 larut fosfat. Sedangkan isolat K3.3 melarutkan fosfat yang berikatan dengan $\mathrm{Ca}$ dengan kelarutan 58,6 mg L-1. Isolat A.4 diidentifikasi sebagai Burkholderia gladioli, isolat K3.1 diidentifikasi sebagai Burkholderia arboris, 
dan isolat K3.3 diidentifikasi sebagai Burkholderia seminalis.

\section{UCAPAN TERIMA KASIH}

Semua bagian dalam penelitian ini didukung oleh Departemen Riset dan Pengembangan, PT. Sampoerna Agro, Tbk.

\section{DAFTAR PUSTAKA}

Acevedo E. et al. 2014. 'Phosphatesolubilizing microorganisms associated with the rhizosphere of oil palm (Elaeis guineensis Jacq.) in Colombia', Applied Soil Ecology, 80:26-33.doi: 10.1016/ j.apsoil.2014.03.011.

Behera BC. et al. 2014. 'Diversity, mechanism and biotechnology of phosphate solubilising

microorganism in mangrove-A review', Biocatalysis and Agricultural Biotechnology. Elsevier, 3(2):97110. doi: $10.1016 \quad / j$ .bcab.2013.09.008.

Chakdar H. et al. 2018. 'Characterization of mineral phosphate solubilizing and plant growth promoting bacteria from termite soil of arid region', 3 Biotech. Springer International Publishing, $0(0)$, p. $0 . \quad$ doi: 10.1007/s13205-018-1488-4.

Euler M. et al. 2017. 'Oil Palm Adoption, Household Welfare, and Nutrition Among Smallholder Farmers in Indonesia', World Development. Elsevier Ltd, 93: 219-235. doi: 10.1016/j.worlddev.2016.12.019.

Fuentes-Ram1 LE. et al. 2001. 'Novel nitrogen-fixing acetic acid bacteria, Gluconacetobacter johanne sp. nov. and Gluconacetobacter azotocaptans sp. nov., associated with coffee plants', International Journal of Systematic and Evolutionary Microbiology, 51, pp. 1305-1314. doi: 10.1099/00207713-51-4-1305.

Grichko VP, Glick BR. 2001. 'Amelioration of flooding stress by
ACC deaminase-containing plant growth-promoting bacteria', Plant Physiology and Biochemistry, 39(1):11-17. doi: 10.1016/S09819428(00)01212-2.

Hoffmann MP. et al. 2017. 'Yield gap analysis in oil palm: Framework development and application in commercial operations in Southeast Asia', Agricultural Systems. Elsevier Ltd, 151, pp. 12-19. doi: 10.1016/j.agsy.2016.11.005.

Istina IN. et al. 2015. 'Phosphatesolubilizing Microbe from Saprists Peat Soil and their Potency to Enhance Oil Palm Growth and $\mathrm{P}$ Uptake', Procedia Food Science. Elsevier Srl, 3, pp. 426-435. doi: 10.1016/j.profoo.2015.01.047.

Li Y. et al. 2017. 'Colonization and Maize Growth Promotion Induced by Phosphate Solubilizing Bacterial Isolates'. doi: 10.3390/ijms18071253.

Nautiyal CS. 1999. 'An e a cient microbiological growth medium for screening phosphate solubilizing microorganisms', 170(436), pp. 265-270.

Panda B, Rahman H, Panda J. 2016. 'Phosphate solubilizing bacteria from the acidic soils of Eastern Himalayan region and their antagonistic effect on fungal pathogens', Rhizosphere. Elsevier, 2, pp. 62-71. doi: 10.1016/j.rhisph.2016.08.001.

Peix A. et al. 2001. 'Growth promotion of common bean (Phaseolus vulgaris L.) by a strain of Burkholderia cepacia under growth chamber conditions', 33, pp. 1927-1935.

Qian,Y. et al. 2010. 'Characterization of Phosphate Solubilizing Bacteria in Sediments from a Shallow Eutrophic Lake and a Wetland: Isolation, Molecular Identification and Phosphorus Release Ability Determination', pp. 8518-8533. doi: 10.3390/molecules15118518. 
Rodríguez H, Fraga R. 1999. 'Phosphate solubilizing bacteria and their role in plant growth promotion', 17, pp. 319-339.

Saikia J. et al. 2018. 'Alleviation of drought stress in pulse crops with ACC deaminase producing rhizobacteria isolated from acidic soil of Northeast India', Scientific Reports. Springer US. 8(1):1-16. doi: 10.1038/s41598-018-21921-w.

Sarker A, Talukder NM, Islam T. 2014. 'Phosphate solubilizing bacteria promote growth and enhance nutrient uptake by wheat', $1, \mathrm{pp}$. 86-93. doi: $10.1080 / 00207729508929050$.

Shahid M, Khan MS. 2018. 'Glyphosate induced toxicity to chickpea plants and stress alleviation by herbicide tolerant phosphate solubilizing

Burkholderia cepacia PSBB1 carrying multifarious plant growth promoting activities', 3 Biotech. Springer Berlin Heidelberg, 8(2):1-17. doi: 10.1007/s13205-018-1145-y.

Sin F, Viruel E. 2011. 'Plant growth promotion traits of phosphobacteria isolated from Puna, Argentina', pp. 489-496. doi: 10.1007/s00203-0110692-y.
Stephen J, Jisha MS. 2011. 'Gluconic acid production as the principal mechanism of mineral phosphate solubilization by Burkholderia sp . (MTCC 8369 )’, 49(Mtcc 8369), pp. 99-103.

Tam HM. 2017. 'Isolation and Identification of Rhizospheric Bacteria in Sugarcane (Saccharum spp . L .) Cultivated on Acrisols of Tay Ninh Province, Vietnam', 8(2): 323-335.

Teng Z. et al. 2018. 'Isolation and characterization of phosphate solubilizing bacteria from rhizosphere soils of the Yeyahu Wetland in Beijing, China', Environmental Science and Pollution Research. Environmental Science and Pollution Research. doi: 10.1007/s11356-018-2955-5.

Wahdi E, Mubarik NR, Widyastuti R. 2016. 'Characterization of Phosphate Solubilising Bacteria from Limestone Quarry in Cirebon Indonesia'. 11(4):312-317.

Zheng B-X. et al. 2019. 'Responses to soil $\mathrm{pH}$ gradients of inorganic phosphate solubilizing bacteria community', Scientific Reports, 9(1):25. doi: 10.1038/s41598-018-37003-w. 